IJASOS- International E-Journal of Advances in Social Sciences, Vol. III, Issue 9, December 2017

\title{
CURRENT ASPECTS OF DEVELOPMENT OF THE ARMED FORCES OF THE REPUBLIC OF BULGARIA AND THE ROLE OF THE DEFENSE ACQUISITIONS IN THE PROCESS OF THEIR REALIZATION
}

\author{
Neno Hristov \\ Colonel Associate professor Ph.D., D. Sc., Military Academy, Sofia, Bulgaria, neno.hristov@gmail.com
}

\begin{abstract}
Changes in the modern security environment, along with the emergence of non-traditional risks and threats, pose new and unexpected challenges to national security. Its direct impact is on the unstable situation in the Western Balkan countries, the Black Sea region, and the crisis in Ukraine, the Middle East and North Africa. The counteraction of the "hybrid" warfare model, combining conventional means with unconventional methods, requires the search for multilateral approaches to addressing security and defense challenges.

The Republic of Bulgaria builds its defense policy within the framework of NATO's collective defense and the Common Security and Defense Policy of the European Union. In this sense, the Armed Forces capability objectives are an essential tool for fulfilling the tasks of protecting national interests, implementing allied engagements and contributing to national security in peacetime. They are used in accordance with the established order of the Constitution, the laws of the country and the observance of international law. The National Defense Strategy defines the following missions for the Air Defense, Support for International Peace and Security and Contribution to National Security in Peacetime.

In order to find an acceptable balance between the available resources and the development of the necessary capabilities to implement the missions and tasks of the Armed Forces, taking into account the changes in the strategic security environment and the medium-term priorities for acquiring new capabilities and upgrading the Armed Forces, we conduct a review of the defense capabilities.
\end{abstract}

Keywords: new capabilities, security environment, defense policy, capability objectives, national security, acceptable balance.

\section{INTRODUCTION}

Changes in the modern security environment, along with the emergence of non-traditional risks and threats, pose new and unexpected challenges to national security. Its direct impact is on the unstable situation in the Western Balkan countries, the Black Sea region, the crisis in Ukraine, the Middle East and North Africa. The counteraction of the "hybrid" warfare model, combining conventional means with unconventional methods, requires the search for multilateral approaches to address security and defense challenges. 
The Republic of Bulgaria builds its defense policy within the framework of NATO's collective defense and the Common Security and Defense Policy of the European Union. In this sense, the Armed Forces capability objectives are an essential tool for fulfilling the tasks of protecting national interests, implementing allied engagements and contributing to national security in peacetime. They are used in accordance with the established order of the Constitution, the laws of the country and the observance of international law. The National Defense Strategy defines the following missions for the Air Defense, Support for International Peace and Security and Contribution to National Security in Peacetime.

In order to find an acceptable balance between the available resources and the development of the necessary capabilities to implement the missions and tasks of the Armed Forces, taking into account the changes in the strategic security environment and the medium-term priorities for acquiring new capabilities and upgrading the Armed Forces, a review of the defense capabilities was made in 2014. An analysis of the implementation of the "Bulgaria's Armed Forces Development Plan" was carried out during the review process. Overall, this plan has achieved its objectives by implementing the following main activities:

- the armed forces of the Republic of Bulgaria have been restructured into a single set of forces and capabilities. Functional Deployment Forces and Defense Forces have been built within this set;

- the structures for command and control at the strategic and operational level were reformed. The reorganizations were tactical;

- a categorization of the military units of the armed forces was adopted in accordance with the established NATO system;

- the armed forces have gone through uniform time schedules for peacetime and crises, which are prepared through uniform programs using unified doctrines, operational procedures and methodologies, and a unified command and control system;

- the peacekeeping personnel of the Ministry of Defense, the structures of direct subordination to the Minister of Defense and the Bulgarian Army, were reduced from 44,100 to 39,600 people, and the number of reservists is up to 3,000 ;

The following main conclusions were drawn from the implementation of the plan actions in 2011-2014:

- the organizational structure and command chain defined in the "White Paper on Defense and Armed Forces of the Republic of Bulgaria" remain valid;

- the development of the concepts of operations under the ten planning scenarios has shown that there is a need for military time to identify formations, structures and personnel to complement the armed forces;

- defense spending over the period 2011-2014 was insufficient to develop effective defense capabilities. The budget of the Ministry of Defense remained below the sanitary minimum of $1.5 \%$ of the gross domestic product of the country in the White Paper;

- the proportion of staff expenditure, current maintenance and capital expenditure ratio is far from the balanced budget allocated to the White Paper for the cost allocation of $60 \%: 25 \%: 15 \%$, especially in the part relating to capital expenditure, i.e. the part concerning the modernization of the armed forces;

- insufficient funds were provided for the implementation of the major projects of the Ministry of Defense's Investment Plan until 2020, which led to difficulties in maintaining the existing capabilities and the impossibility of building new ones;

- the worsened state of armaments and techniques has also reflected on the preparation of the military projections of the armed forces;

- systematic under-financing necessitated an extension of the deadlines for implementation of some of the measures envisaged for implementation in the Plan for Development of the Armed Forces of the Republic of Bulgaria.

An assessment was also made of the fulfillment of the commitments of the Republic of Bulgaria under the Capability Objectives package - 2013. It was found that the implementation of the majority of capability objectives is limited, deficient and lagging behind. This leads to lower levels of interoperability, combat effectiveness and combat ability of declared entities and, ultimately, insufficient capabilities to perform tasks in 
missions and operations as intended. The main reason preventing the implementation of capability objectives and the construction and preparation of the declared formations is the limited financial resource. Regardless of the objective difficulties and the systematic shortage of funds from the last years, the efforts to implement the capability objectives, the construction and the preparation of the declared formations will continue. Particular attention will be paid to the timely certification of declared formations, albeit with limitations inevitable in view of the situation, mainly in the field of combat effectiveness and interoperability. Within the capability objectives 2013 package, by 2020 the priority directions for development of the defense capabilities of our country are:

- achieving a high level of interoperability with the Allies;

- development of the communication and information systems of the deployment forces and for participation in operations and missions abroad;

- Increasing the mobility of the Land Forces formations;

- Developing the capabilities of the Navy to combat maritime mines, sea and air enemies;

- development of aircraft self-defense systems;

- development of intelligence, surveillance and targeting capabilities.

In response to the challenges arising from the events in Ukraine, the Middle East and North Africa, a "readiness action plan" (RAP) was adopted at the Wales Summit (September 2014). The plan strengthens the Alliance's collective defense and crisis management capabilities. The tasks outlined in it require the earliest possible implementation and include the Assurance Measures and Adaptation Measures. The broad scope and interdependence of the components of the plan require commitment and solidarity from armed forces allies.

National commitments under this plan include mainly maintaining capabilities for the implementation of the Air Policing mission within NATO's Integrated Anti-Air Defense System and Missile Defense (NATINAMDS), increasing the number of joint exercises on the territory of the country and in the Black Sea, Building a NATO Force Integration Unit (NFIU) on our territory, contributing to the construction of the Very High Readiness Joint Task Force (VJTF) and to the Enlargement Process Plan ahead of NATO planning.

To build a modern and capable army, capability-based defense planning is used in modern conditions to ensure the construction, development, maintenance and use of the necessary defense capabilities. Its implementation should be carried out in a unified system. Such a system for managing the development of the armed forces fig. 1 was adopted and this system included: a Subsystem for Required Operational Capabilities (ROC); Integrated Defense Resources Management Subsystem; The Defense Acquisition Subsystem (AS); Human Resource Management Subsystem. Prior to the introduction of an Arms Development Management System, the Integrated Resource Management Subsystem, and subsequently the Defense Acquisition Subsystem, functioned. The Subsystem for Necessary Defense Capabilities was launched and the Armed Forces Development Management System in place. Thus, in practice, there are currently three subsystems functioning with the appropriate advice - defense capabilities, weapons, program, but there is no document to regulate the introduction and functioning of the Armed Forces Development Management System. The process of operation of the subsystems is interlinked and their cooperative activity is the guarantee for an effective management of the development of the armed forces.

In line with national commitments, we should cover the minimum requirements for the capabilities of the Armed Forces, allocated in the following seven areas: training; Deployment; Combat effectiveness; support; Command and control; defense; Information security. Within these areas, the priority directions for the development of the capabilities of our country by 2020 will be concentrated mainly in the areas of "Combat efficiency", "Command and management" and "Information security". It is in these three areas that there is the most serious shortage of capabilities needed to conduct modern military operations. This lack of abilities has a direct and negative relation towards the capabilities of the armed forces to reliably guarantee the country's air and maritime sovereignty as well as full participation in NATO and EU multi-national joint missions, operations and exercises.

For the functioning of small but well-armed and effective armed forces, systematic efforts are needed to maintain armaments, combat equipment, and bring them into line with the requirements to reach defense capabilities to perform assigned missions and tasks. This is a process that requires considerable resources and effort to implement it. Modernization and rearmament should be seen as a continuous process involving a combination of complex activities. Their realization is in direct dependence on resources, the allocation of which can not be 
relied on by market regulatory mechanisms. The implementation of the process of modernization of the Armed Forces requires considerable financial resources, the provision of which should be realized by the Republican budget. Unfortunately, in recent years this has been achieved within the approved financial resource for the Ministry of Defense, in compliance with the State Budget Act. All this necessitates the need to build and maintain a comprehensive system by which objectively and transparently for the society to be determined the needs for development of armaments and techniques and through which they have to be managed so that the limited resources provided are spent economically and efficiently. It is necessary to ensure the following conditions in the system operation:

- the development of armament and equipment are oriented towards bridging the gap between existing defense capabilities and those required for the successful execution of assigned implementation missions and tasks of the armed forces;

- Ensuring the possibility of coordination in the activities of the armed forces participating in the process of development of armaments and techniques: the departments and structures that define the directions for the development of the armed forces: the research centers that will give and implement the proposals for realization of the development: manufacturers who will implement manufacturing, warranty and support this process of exploitation, as well as the realization of modernization, training of personnel who will operate and maintain good working order of the devices:

- implementation of procedures to enable further control of decisions, ensuring economical and efficient management of scarce defense resources.

Bulgaria 2020 Armed Forces Development Defense Program does not envisage organizational and structural changes in the research units in the higher education institutions and the Defense Institute, which is a positive indication and a prerequisite for preserving the continuity and is of exceptional importance for the realization of research in the interest of defense. The main guidelines for carrying out scientific research, support and support for scientific projects and experiments will be directly related to the process of rearmament of the armed forces. Research priorities are needed to ensure implementation of modernization, development of combat and support capabilities, communication-information systems and cybersecurity. Scientific units are commissioned to conduct research on new weapons, equipment, systems and ammunition, developing tactical and technical assignments and projects, and controlling the quality of defense products delivered.

As already noted, it is not irrelevant how the financial security of the defense acquisition will take place. The main funding source in the Program is to be implemented through the budget, but it can also be done from external sources such as the NATO Security Investment Program (NSIP), European programs, bilateral mechanisms for funding, additional funds from the release of redundant and needless movable property and real estate. The establishment and maintenance of an effective Defense Acquisition System is envisaged and the PRINCE 2 Controled Environments (PRojects IN Controled Environments) methodology, based on controlling the processes for effective project management, is to be based on the management of investment projects. In the process of implementing investment projects, the Ministry of Defense needs to make more active use of the capabilities of NATO agencies. Such cooperation will enable the armed forces to develop fruitfully in the following directions:

- From a military point of view: The realization of projects through the agencies ensures the interoperability of the systems built with those of NATO and the member states, which will be built in compliance with all Allied standardization requirements and in keeping with the current NATO Architecture Framework. For small countries such as Bulgaria, the effect can easily be multiplied across the security sector and help to build a state-of-the-art high-tech, yet coherent environment for command and control at the national level (or modernization of the existing one);

- From a financial / economic point of view, NATO agencies do not calculate profit when they are priced, and only costs for the acquisition of material, labor and project management (management costs) are included in the price. Agencies have concluded framework supply contracts with leading European and global companies under which companies undertake to deliver the necessary equipment at preferential prices. This enables agencies to execute contracts at very favorable financial terms for end users. The award of certain projects to the agencies will ensure maximum transparency on the way budgetary resources are spent as they are subject to annual financial audit and, in practice, there is currently no reported case of bad or corrupt practices in their activities;

- From an industrial and scientific and technological point of view: Bulgarian defense industry companies and 
scientific organizations will have the opportunity to participate as subcontractors and respectively to have the opportunity to build long-term cooperation and access to some new technologies owned by the agencies.

Greater initiative is needed in the use of commercial companies with the Minister of Defense, the Industrial Forum, the establishment of a National Defense Cluster, the use of NATO, EU, regional, multilateral and bilateral instruments, and the introduction of the Institute of the so „In-house” assignment in the Public Procurement Act, for which a legal basis should be created for the direct conclusion of contracts between the contracting authority and a company or a state enterprise in order the Minister of Defense be able to enter into contracts with commercial companies that meet the statutory criteria. This is also a real prerequisite for the financial and economic stabilization of most of the companies and will lead to increased dividend and tax revenues. A possible way to exempt the Ministry of Defense from unnecessary activities and unnecessary assets is through the creation of a special Smart Defense Fund as one of the founding factors with immediate effect on modernization projects. The same should be done on the basis of the defense-related products sold by the Ministry of Defense, and the accumulated funds are used to support the existing capabilities and the implementation of the modernization projects.

The effective functioning of the defense acquisition system, project management, the more active use of the capabilities of NATO agencies and the benefits of such international cooperation is of great importance for the process of modernization, the acquisition of new defense capabilities and the creation of conditions for reinvestment in Defense.

\section{CONCLUSIONS}

As a result of the review of the capabilities of the Armed Forces, the identified shortfall in capabilities and the minimization of the negative impact on the ability of the Armed Forces to fulfill in full the missions and tasks assigned to them, the main directions were set in which the construction of new defense capabilities need to be made, through the realization of investment projects. As major investment projects for the modernization of the Armed Forces, under the conditions of resource constraints, the Program includes re-equipment projects.

These major investment projects are in line with the needs for additional defense capabilities of the Armed Forces, with a horizon for acquisition by and beyond 2020. Their successful realization is directly dependent not only on the financial feasibility of implementation but also on the available scientific potential and its possibilities for conducting effective scientific and technical support of the investment projects as well as the capabilities of the Bulgarian defense industry.

The implementation of modernization projects will help overcome the technological backwardness of the armed forces in the area of defense capabilities and will have a catalysing economic effect for the defense industry and the economy of the country. The funds invested in modernization mean innovation and development of the scientific and productive potential of a country.

\section{REFERENCE LIST}

Andy Jordan, (2013) Risk Management for Project Driven Organizations, PM Publishing News.

Allied Command Transformation, Smart Defence Projects and Proposals, 2013.

American Systems Corporation Risk Management Process and Implementation, 2003

Barros M., Werner C., Travassos G., (2002) Project Management Knowledge Reuse through Scenario Models, Springer Berlin Heidelberg.

Broadleaf Capital International PTY LTD, the Australian and New Zealand Standard on Risk Management, 2004

Canberra, Department of Defence, Defence Capability Development Manuel, 2006.

Charter of the NATO Support and Procurement Organization, 2012

Child, Dennis, (1990) The essentials of factor analysis (2nd ed.), New York, NY, US: Cassell Educational. 
Convey S., (1990) Седем навика на високо ефективни хора, New York, Simon Schuster.

Crouhy M., Galai D., and Mark R., (2005) Essentials of Risk Management, McGraw-Hill.

David I. Cleland, (2006) Project Management Handbook: Planning, Organizing, and Controlling International Projects, McGraw-Hill Companies, Inc.

David Hillson, (2002) Use a Risk Breakdown Structure to Understand Your Risks.

DRMM Users Guide Vol I-IV, Institute for Defence Analysis, USA, 2002

Edwin J. Elton, Martin Gruber, Stephen Brown, and William N. Geotzmann, (2006) Modern Portfolio and Investment Analysis, 7 the edition, Hoboken, NJ: John Wiley, December.

Terziev, V., (2013) Aktivniq model na socialnata programa I neinoto strategichesko pedimstvo.12th International Scientific Conference: Management Horizons in Changing Economic Environment \& Visions and Challenges, Kaunas, pp.917-932.

Terziev, V., S. Dimitrova, (2014) Socialnata adaptaciq kato socialen process pri adaptiraneto ma. -Enterprise and Competitive Environment, Mendel University in Brno, International Conference Brno, pp.28-44.

Terziev, V., (2015) Socialna adaptaciq kato na voennoslujeshtiti osvobodeni ot voenna slujba, v dinamichna socialna sreda adaptiraneto na voennite. -Сборник статей Международной научно-практической конференции „Прорывные экономические рефрормы в условиях риска и неопределености“, pp.1216.

Terziev, V., S. Dimitrova, (2015) Finansova sigurnost - osnova na strategicheski resheniq za upravlenie na resursite za sigurnost I otbrana. Сборник статей Международной научно-практической конференции „Прорывные экономические реформы в условиях риска и неопределености“, pp.65-69.

Terziev, V., (2017) Racionalizirane na upravlenskite resheniq za ikonomichno, efektivno i efikasno izrahodvane na resursi za sigurnost i otbrana. Oxford Journal of Legal studies, Issue 4 (2), Volume 37. Oxford University Press, pp.940-947.

Terziev, V., (2016) Sistema za upravlenie na choveshkite resursi w oblasta na sigurnostta i otbranta:socialni politiki za socialni deinosti. -XXXII Международная научно-практическая конференция, Евразийский союз ученых (ЕСУ), Ежемесячный научный журнал № 12 (33), pp.84-90.

Terziev, V., (2017) Nacionalna sigurnost na republika Bykgaria. -The Chinese Journal of International Politics Issue 4 (2), (Winter), Volume 10. Oxford University Press, pp.893-908.

Terziev, V., N. Nichev., Stefan B., Nacionalna sigurnost na republika Bykgaria. Science and practice: Collection of scientific articles. pp. 12-21.

Terziev, V., (2017) Nacionalna sigurnost na republika Bykgaria. International Journal of Management and Applied Science, Volume-3, pp. 22-28.

Terziev, V., E.Stoyanov \& M.Georgiev (2017) Modelyt balansirana karta za ocenka kato instrument za usywyrshenstvane na upravlenieto $v$ rabotata na nacionalnata Sistema za otbrana i sigurnostThe balanced scorecard model as atool for improvement of the national defense system management. Research: tendencies and prospects: Collection of scientific articles. pp.7-11.

Terziev, V., M. Georgiev, (2017) Akcenti na razvitieto na ideqta za "balansirana karta na rezultatite" kato model za upravlenie na strategicheskoto razwitie i control. Proceedings of SOCIOINT 2017- 4th International Conference on Education, Social Sciences and Humanities, pp.607-610.

Terziev, V., N.Nichev, (2017) Analiz na sredata za funkcionirane na voennata obrazuvatelna sistema i neinoto vyzdeistvie vyrxu podgotovkata na kadet za voenna profesionalna deinost v Republika Bulgariq. Proceedings of SOCIOINT 2017- 4th International Conference on Education, Social Sciences and Humanities, pp.627-630. 